\title{
Silver-Modified $\beta$-Cyclodextrin Polymer for Water Treatment: A Balanced Adsorption and Antibacterial Performance
}

\author{
Xin Wang ${ }^{1}$, Huafeng Chen ${ }^{2}$, Jianyu Wang ${ }^{2}$, Yi Zhou ${ }^{2}$, Changzheng Cui ${ }^{2}$ and Yanbo Zhou ${ }^{1,2, *}$ \\ 1 School of Carbon Neutrality Future Technology, East China University of Science and Technology, \\ No. 130 Meilong Road, Shanghai 200237, China; wangxinvicky@163.com \\ 2 State Environmental Protection Key Laboratory of Environmental Risk Assessment and Control on \\ Chemical Process, East China University of Science and Technology, No. 130 Meilong Road, \\ Shanghai 200237, China; lscschf@163.com (H.C.); wangjianyull@foxmail.com (J.W.); \\ yizhou@ecust.edu.cn (Y.Z.); cuichangzheng@ecust.edu.cn (C.C.) \\ * Correspondence: zhouyanbo@ecust.edu.cn; Tel.: +86-21-64250225
}

check for updates

Citation: Wang, X.; Chen, H.; Wang,

J.; Zhou, Y.; Cui, C.; Zhou, Y.

Silver-Modified $\beta$-Cyclodextrin Polymer for Water Treatment: A

Balanced Adsorption and

Antibacterial Performance. Water

2021, 13, 3004. https://doi.org/

10.3390/w13213004

Academic Editors: Layla Ben Ayed,

Eleni Golomazou, Panagiotis Karanis,

Patrick Scheid, Ourania Tzoraki,

Anna Lass and Muhammad Shahid Iqbal

Received: 29 September 2021

Accepted: 21 October 2021

Published: 26 October 2021

Publisher's Note: MDPI stays neutral with regard to jurisdictional claims in published maps and institutional affiliations.

Copyright: (C) 2021 by the authors. Licensee MDPI, Basel, Switzerland. This article is an open access article distributed under the terms and conditions of the Creative Commons Attribution (CC BY) license (https:/ / creativecommons.org/licenses/by/ $4.0 /)$.

\begin{abstract}
Water pollution caused by organic pollutants and pathogenic microorganism is a critical issue. In this study, we reported a silver-modified $\beta$-cyclodextrin polymer (CD-CA/PDA-Ag) used for the removal of dyes and the suppression of microorganisms from water. In order to avoid silver nanoparticles agglomeration, the material was first coated with polydopamine (PDA) on $\beta$-cyclodextrin matrix, whose reducing catechol groups subsequently immobilized silver ions in situ to form uniformly dispersed silver nanoparticles. CD-CA/PDA-0.5Ag displayed a high adsorption capacity of methylene blue $(535.93 \mathrm{mg} / \mathrm{g})$, which is mainly attributed to electrostatic interactions, host-guest inclusions and $\pi-\pi$ bond stacking effects. Furthermore, both diffusion inhibition zone tests and colony formation unit tests were investigated, which showed excellent antimicrobial capability on Escherichia coli (E. coli) and Staphylococcus aureus (S. auerus). Overall, CD-CA/PDA-Ag proved to have an excellent adsorption capacity and antibacterial performance, which provides a great potential in water purification.
\end{abstract}

Keywords: cyclodextrin polymer; adsorption; antibacterial; polydopamine; nano-silver

\section{Introduction}

Water pollution caused by organic chemicals and pathogenic microorganisms is a critical issue as it affects human health and the ecosystem as a whole [1]. Adsorption as a modern technology has gained a lot of attention in the wastewater treatment field [2] due to high efficiency, ease in operation, cost efficiency and reusability [3]. Absorbents are generally used to capture dyes, heavy metals [4], endocrine disruptors [5] and other noxious pollutants [6] from water. However, only a few studies have focused on their use for the removal of microorganisms from wastewater and their efficiency as antimicrobial agents. The World Health Organization stated that microbial hazards are the primary concern for drinking water quality in both developed and underdeveloped countries [7]. Although the water treatment technology is relatively mature, drinking water is extremely susceptible to contamination by various bacteria, viruses, protozoa and parasites during production and transportation. Sand filters or activated carbon plays a primary role in the last step of water treatment [8], however, the filtrate contains comparable amounts of biomass [9]. This biomass triggers regrowth and becomes a vehicle for spreading diseases, thereby posing a higher health risk to water consumers [10]. With the outbreak of the COVID19 epidemic, water safety and the removal of pathogenic microorganisms from water have drawn a lot of attention.

Some carbon-based adsorbents which were widely used for adsorption [11], could be contaminated by biological fouling during long-term use, thereby inhibiting their adsorption performance [12]. The choice of adsorbent is an essential step [13] in the 
adsorption process [14]. The introduction of antibacterial properties ensures the prevention of adsorbent contamination by microorganisms during long-term use. Some adsorbents have bactericidal properties, but their adsorption and sterilization abilities cannot meet the actual treatment requirements concurrently [15]. Therefore, the development of a multifunctional adsorbent with antibacterial properties is crucial. The antibacterial function of traditional adsorbents can be realised through modifications. Some novel antibacterial methods are developed; the balance between antibacterial function and the removal of pollutants has become a research focus [16].

In recent years, cyclodextrin and its polymers have greatly attracted scientific attention in the treatment of environmental contaminants because of their special cavity structure [17], host-guest interaction [18] and the potential for disinfection [19]. Cyclodextrin properties of insolubility and availability can be improved by chemical modification [20]. Liu et al. developed a new type of surface enhanced Raman scattering substrate with an Ag nanoparticle monolayer functionalised by mono-6-deoxy-6-thio- $\beta$-cyclodextrin to efficiently capture and detect dye in wastewater [21]. Zhou et al. investigated different photo-oxidation systems and showed that modification with cyclodextrin can facilitate the mineralisation of bisphenol-A (BPA) in the photocatalytic oxidation process [22]. The structure of cyclodextrins can be modified and used as virucidal agents in pharmaceutical application due to their interactions with the viral lipids [23]. We successfully synthesised $\beta$-cyclodextrin polymers (CD-CA) using citric acid (CA) as a linker; the polymers exhibited intriguing capabilities to adsorb heavy metals [24], dyes and endocrine disruptors [15]. However, cyclodextrin materials need to be further modified for the removal of hazardous chemicals and for the development of their antibacterial properties [23].

Silver is extensively used for water disinfection due to its outstanding properties; it has less restrictions and possesses a broad-spectrum of antibacterial activity [25,26]. Currently, sliver is widely used for antibacterial functional modification of polysaccharide polymer [27], inorganic nanomaterials [28], metal [29] and poly membrane [30]. The method for anchoring silver typically involves the amine, hydroxyl or phenolic hydroxyl groups on the carrier as the active site for chelating silver ions; silver ions are reduced to silver particles by adding chemical reducing agents [31]. Some researchers prepared the $\mathrm{TiO}_{2} / \mathrm{Ag}$ [24] or $\mathrm{Ag} / \mathrm{gC}_{3} \mathrm{~N}_{4}$ [32] nanocomposite by using dopamine as a reducing agent. However, the reduction of specific surface area due to agglomeration of silver significantly reduces antibacterial activity [26]. Therefore, solving the agglomeration problem of $\mathrm{Ag}$ is an important issue for developing multifunctional antibacterial adsorbents.

As a green polymer material, dopamine contains abundant catechol groups on its surface, which can effectively induce the growth of silver particles in situ [24]. Moreover, dopamine can form polydopamine through self-polymerisation, and its special network structure makes it highly modifiable. The introduction of cyclodextrin and polydopamine provides a convenient way for developing antibacterial materials. Enhancing synergistic adsorbents prevent the deterioration of water.

In this work, we developed a multifunctional antibacterial polymer (CD-CA/PDA-Ag) through an environmentally friendly method. Characterization was performed by Fourier transform infrared spectroscopy and X-ray photoelectron spectroscopy. The adsorption and antibacterial properties of the material were verified through the adsorption of $\mathrm{MB}$ and the inhibition of Escherichia coli and Staphylococcus aureus.

\section{Materials and Methods}

\subsection{Chemicals and Materials}

Dopamine hydrochloride (DH) (CAS: 62-31-7, >98\%, Shanghai debai Biotechnology Company, Shanghai, China), $\beta$-cyclodextrin (CAS: 68168-23-0, >99\%, Aladdin Reagent Company, Shanghai, China), Tris (hydroxymethyl) aminomethane (CAS: 77-86-1, >98\%, Shanghai Macklin Biochemical Company, Shanghai, China), MB (CAS: 12262-49-6, > 95\%, Shanghai Debai Biotechnology Company, Shanghai, China), $\mathrm{AgNO}_{3}$ (CAS: 7761-88-8, $\geq 98 \%$, Shanghai Maclin Biochemical Technology Company, Shanghai, China), E. coli, 
S. aureus, (Suzhou Beina Chuanglian Biotechnology, Suzhou, China) were purchased from commercial corporation.

\subsection{Preparation of Antibacterial Adsorbent}

The preparation of CD-CA/PDA: $2 \mathrm{~g}$ of CD-CA were added in $200 \mathrm{~mL}$ of Tris (Tris(hydroxymethyl)methyl aminomethane) buffer solution ( $50 \mathrm{mM}, \mathrm{pH}=8.0-8.5)$ under constant magnetic stirring for a few minutes. A sufficient amount of dopamine hydrochloride $(\mathrm{DH})$ was added to the above solution to obtain $0.2,0.5,1$ and $2 \mathrm{~g} / \mathrm{L}$ concentrations. Following continuous magnetical stirring at $500 \mathrm{r} / \mathrm{min}$ for 3, 6, 12 and $24 \mathrm{~h}$, the as-prepared solution was centrifuged at $4000 \mathrm{r} / \mathrm{min}$ for at least five times. After washing and separation, $\mathrm{CD}-\mathrm{CA} / \mathrm{PDA}$ was dried at $50{ }^{\circ} \mathrm{C}$ for further use. The specific steps of CD-CA [33] and CD-CA/PDA are shown in our previous research [24].

The preparation process of CD-CA/PDA-xAg: CD-CA/PDA was added in $100 \mathrm{~mL}$ of $\mathrm{AgNO}_{3}$ solution $(0.5,1,2$ and $4 \mathrm{~g} / \mathrm{L}$ ) separately, and stirred magnetically at $500 \mathrm{r} / \mathrm{min}$ for $5 \mathrm{~h}$. The solid was washed off alternately by water/alcohol for 5 times, and the product was dried at $50^{\circ} \mathrm{C}$. Products were named as CD-CA/PDA-xAg (X = 0.5, 1, 2, 4 represents the concentration of silver nitrate during synthesis). The preparation steps of the CD-CA/PDA-xAg are presented in Figure 1.

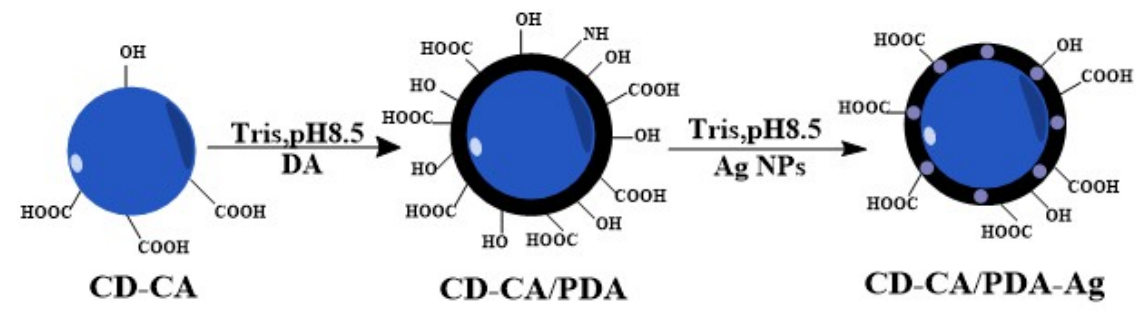

Figure 1. Preparation steps of CD-CA/PDA-xAg.

\subsection{Antibacterial Experiment}

The experiments of inhibition zone and colony forming unit was conducted [26] Details are shown in the Supplementary Material.

\subsection{Adsorption Experiment}

The adsorption experiments were initiated by adding $0.1 \mathrm{~g}$ CD-CA/PDA-xAg to the $\mathrm{MB}$ solution ( $\mathrm{pH}$ 5.5) (with the ratio of adsorbent mass to pollutant solution volume as $1.0 \mathrm{~g} / \mathrm{L}$ ). The samples at time nodes of $0,2,5,10,20,30,60,120$ and 180 min were collected to investigate the influence of silver content on adsorption performance. The concentration of filtrate was determined by using a UV spectrophotometer (Unico 2802) that helps to measure the maximum absorbance. The maximum absorption wavelength of methylene blue was noted at $665 \mathrm{~nm}$. The concentration was analyzed and the $q_{t}$ value was calculated according to Formula (1), as follows:

$$
q_{t}=\frac{\left(C_{0}-C_{t}\right) V}{m}
$$

where $C_{0}(\mathrm{mg} / \mathrm{L})$ and $C_{t}(\mathrm{mg} / \mathrm{L})$ represent the initial and residual the concentration of the pollutants, respectively. $V(\mathrm{~mL})$ represents the volume of the pollutant solution and $m(\mathrm{mg})$ is to the total mass of the adsorbent.

\subsection{Initial $p H$ Effect on $M B$ Adsorption}

The prepared MB solution was diluted to $300 \mathrm{mg} / \mathrm{L}$ for use, and then $100 \mathrm{~mL}$ of the above solution was put into a $250 \mathrm{~mL}$ Erlenmeyer flask. The $\mathrm{pH}$ of the solution was adjusted to $2,4,6,8,9,10,11,12$ separately by adding the appropriate concentrations of $\mathrm{NaOH}$ and $\mathrm{HCl}$. After adding 0.1g CD-CA/PDA-0.5Ag, the Erlenmeyer flask was sealed with a parafilm and transferred to a constant temperature shaken at $25^{\circ} \mathrm{C}$ for $12 \mathrm{~h}$. After 
the adsorbent was completely precipitated, the supernatant was then taken to test the concentration of residual pollutants.

\subsection{Characterisation of Antibacterial Adsorbent}

In order to analyze the effect of nano-silver on the chemical property of CD-CA/PDA, obtain the relationship between nano-silver and CD-CA/PDA, and observe the morphological characteristics of nano-silver formed on CD-CA/PDA, the following characterisations were investigated.

Fourier infrared spectroscopy (FT-IR) was performed by using Nicolet 6700 infrared spectrometer (America). The instrument used for X-ray photoelectron spectroscopy (XPS) is produced by (Rigaku Corporation, Japan), ranging from $3^{\circ}$ to $40^{\circ}$. Transmission electron microscope (TEM) sample characterization was performed with JEM-2100 high-resolution TEM (Japan) with a magnification of $2 \mathrm{Kx}$ to $1500 \mathrm{Kx}$. Field emission scanning electron microscope (FESEM) analysis was performed by using Gemini SEM500 FESEM (Germany). The descriptions of sample processing in preparation for imaging were added in the Supplementary Material.

\section{Results and Discussions}

\subsection{Characterisations of $C D-C A / P D A-x A g$}

FTIR spectra of CD-CA/PDA and CD-CA/PDA-Ag are shown in Figure 2. The peak positions at 956, 1028, 1153 and $2929 \mathrm{~cm}^{-1}$ corresponded to the R-1,4 framework vibration on $\beta-\mathrm{CD}$, the stretching vibration of $\mathrm{C}-\mathrm{O}$ and $\mathrm{C}-\mathrm{O}-\mathrm{C}$ and the aliphatic $\mathrm{C}-\mathrm{H}$ bond, respectively. No obvious peak intensity change and peak displacement of the materials were found after the modification of silver, indicating that the preparation process of the material loaded with silver nanoparticles (AgNPs) did not modify the skeleton of cyclodextrin [34]. The peak at $1737 \mathrm{~cm}^{-1}$ represents the stretching vibration of the $\mathrm{C}=\mathrm{O}$ on the CD-CA. No obvious change was found in the intensity and position of the absorption peak after the AgNPs were loaded, indicating that the ester group and the carboxyl groups on the surface of CD-CA/PDA were not consumed [35]. Thus, the basic structure of CD-CA was not destroyed. In addition, the characteristic absorption peak at $3410 \mathrm{~cm}^{-1}$ represented the stretching vibration of the O-H on CD-CA/PDA. After the modification of AgNPs, the absorption peak of O-H on CD-CA/PDA-Ag shifted to $3423 \mathrm{~cm}^{-1}$. This finding is attributed to the reduction of $\mathrm{Ag}^{+}$by the catechol groups, which led to the consumption of phenolic $\mathrm{O}-\mathrm{H}$ and the changes of the interaction force provided by the hydrogen bond between CD-CA and PDA [24]. $\pi-\pi$ Stacking force is formed between the CD-CA and PDA molecules due to the modification of PDA [24]. During the formation of AgNPs, the phenolic hydroxyl group was reduced to phenone groups, which caused the weakening of the $\pi-\pi$ stacking and led to the shift of the characteristic absorption peak from $1587 \mathrm{~cm}^{-1}$ to $1595 \mathrm{~cm}^{-1}$ [36].

After the loading of AgNPs, the phenolic hydroxyl groups on CD-CA/PDA were consumed and converted into ketone groups. However, the basic molecular structure of CD-CA and its effective groups were not lost, and the matrix material still had good adsorption properties.

To further verify the success of the loading of AgNPs on CD-CA/PDA, the surface chemical compositions of adsorbents before and after loading AgNPs were examined by XPS, as shown in Figure 3. The full spectrum shows that the bound energy has absorption peaks at around $284.8,402.4$ and $532.5 \mathrm{eV}$, which corresponded to the elements $\mathrm{C}, \mathrm{N}$ and $\mathrm{O}$, respectively. Figure $3 \mathrm{~b}$ shows absorption peaks at 367.8 and $373.8 \mathrm{eV}$, which corresponded to the $\mathrm{Ag}$ element ( $\mathrm{Ag} 3 \mathrm{~d} 5 / 2$ and $\mathrm{Ag} 3 \mathrm{~d} 3 / 2$, respectively). By comparing the $C$ 1s diagrams of CD-CA/PDA (Figure 3c) and CD-CA/PDA-Ag (Figure 3d), the absorption peaks appearing at 285.0, 286.7, 288.0 and $289.2 \mathrm{eV}$ corresponded to $\mathrm{C}=\mathrm{C} / \mathrm{C}$ $\mathrm{C} / \mathrm{C}-\mathrm{O} / \mathrm{C}-\mathrm{H}, \mathrm{C}-\mathrm{N}, \mathrm{C}=\mathrm{O}$ and $\mathrm{O}-\mathrm{C}=\mathrm{O}$, respectively [37]. The $\mathrm{N} 1$ s diagrams of $\mathrm{CD}-$ $\mathrm{CA} / \mathrm{PDA}$ (Figure $3 \mathrm{e}$ ) and CD-CA/PDA-Ag (Figure $3 \mathrm{f}$ ) revealed the absorption peak at $401.7 \mathrm{eV}$, which represented the positively charged ammonia species on the surface. In 
addition, the absorption peak (399.4 eV) of amine at CD-CA/PDA shifted to $400.1 \mathrm{eV}$ after silver modification, which probably indicated that the amine groups (substituted amine, indolyl and imino groups) on the surface of the material were oxidised [38]. Moreover, the absorption peak at the bound energy of $400.1 \mathrm{eV}$ also shifted to $400.7 \mathrm{eV}$, which is the spontaneous breaking of the carbon-nitrogen bond (such as indole) during the reduction of silver ions by PDA [39].

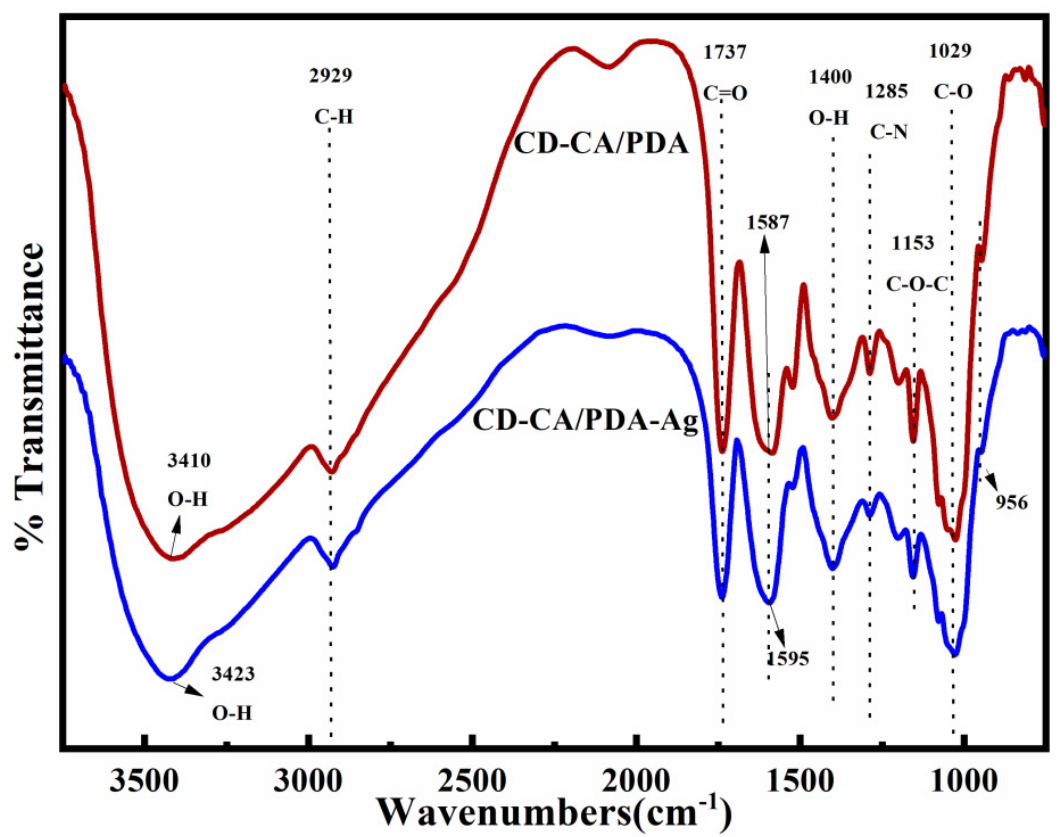

Figure 2. FT-IR analysis of CA-CA/PDA before and after loading AgNPs.

To determine the influence of different concentrations of $\mathrm{AgNO}_{3}$ on the silver content in the final CD-CA/PDA-xAg, EDS analysis was conducted. As shown in Figure 4a, the element of Ag in CD-CA/PDA was not detected on the EDS spectrometer. When $x$ was adjusted to 0.5, 1.0, 2.0 and 4.0, the corresponding mass fractions of Ag were 3.90\%, $6.32 \%, 7.08 \%$ and $13.37 \%$, respectively. With increasing concentration of $\mathrm{AgNO}_{3}$, more AgNPs were reduced to combine with CD-CA/PDA. This is because the increase of $\mathrm{Ag}^{+}$ concentration led to a corresponding increase in the possibility of its contact reaction with the catechol groups on CD-CA/PDA, which prompted the reduction reaction to proceed. In addition, the mass fraction of $\mathrm{C}$ element also decreased slightly with the increase of $\mathrm{Ag}$ content, which may be due to the formation of AgNPs on the surface of CD-CA/PDA, consuming a small amount of phenolic hydroxyl groups [38].

The distribution of Ag in the material was detected by TEM, and there was no AgNP on the CD-CA/PDA (Figure 4a). The images of CD-CA/PDA-0.5Ag, CD-CA/PDA-1Ag and CD-CA/PDA-2Ag, showed that AgNPs are formed on the surface or inside CD-CA/PDA, and the distribution of $\mathrm{Ag}$ was relatively even. With increasing $\mathrm{AgNO}_{3}$ concentration, the distribution density of AgNPs increased. However, the agglomeration of AgNPs was found in CD-CA/PDA-4Ag (Figure 4e). An increase in the concentration of $\mathrm{Ag}^{+}$increased the formation of AgNPs, which in turn caused the agglomeration of AgNPs.

Therefore, an increase in the concentration of $\mathrm{AgNO}_{3}$ under the synthesis conditions led to a gradual increase in the silver content of CD-CA/PDA-xAg. No agglomeration was observed on the surface of CD-CA/PDA-xAg when the concentration of $\mathrm{AgNO}_{3}$ was less than or equal to $2 \mathrm{~g} / \mathrm{L}$. In addition, the AgNPs were well dispersed in the PDA layer. However, aggregation of AgNPs started with an increase of concentration of $\mathrm{AgNO}_{3}$.

The FESEM analysis on the material shown in Figure 5, further analysed the composition and distribution of each element. The surface of CD-CA/PDA was smooth and uniform without loose and porous structures, attributed to the adhesion of the dense polydopamine layer. This nature of the polymer also provided a good platform for the dis- 
persion of AgNPs. Comparing Figure $5 a$ to Figure 5b, AgNPs were found to be uniformly attached to the surface of the polydopamine layer. A few AgNPs were embedded in the PDA layer or completely penetrated the CD-CA/PDA.
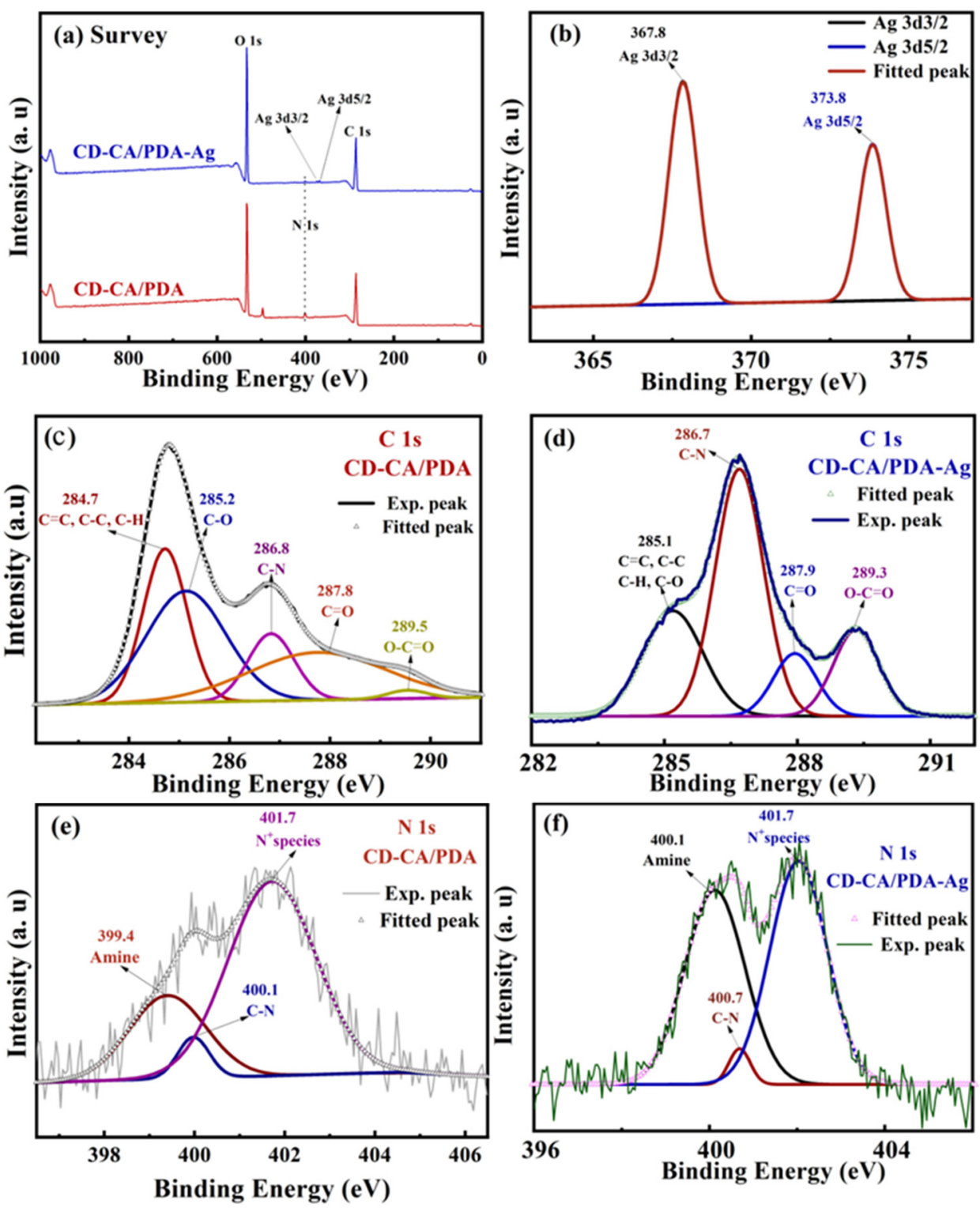

Figure 3. XPS survey spectra of CD-CA/PDA and CD-CA/PDA-Ag (a). High-resolution spectra of $\mathrm{Ag} 3 \mathrm{~d}$ peaks for CD-CA/PDA-Ag (b). High-resolution spectra of C 1s peaks for CD-CA/PDA (c) and CD-CA/PDA-Ag (d). High-resolution spectra of $\mathrm{N}$ 1s peaks for CD-CA/PDA (e) and CD-CA/PDA-Ag (f).

To qualitatively analyse the different elements on the surface of the material, a scanning analysis of $\mathrm{C}, \mathrm{N}, \mathrm{O}$ and $\mathrm{Ag}$ elements on CD-CA/PDA-0.5Ag was performed. The basic elements of N (Figure 5c), O (Figure 5d) and C (Figure 5f) were evenly distributed in some areas of the material, and the composition of Ag was less (Figure 5e); it was distributed in the edges or wrinkled areas of the material. Therefore, we found that the AgNPs in CD-CA/PDA-0.5Ag were evenly distributed on the surface or inside the PDA layer. Each element was evenly distributed in the material, and no obvious agglomeration was found. 

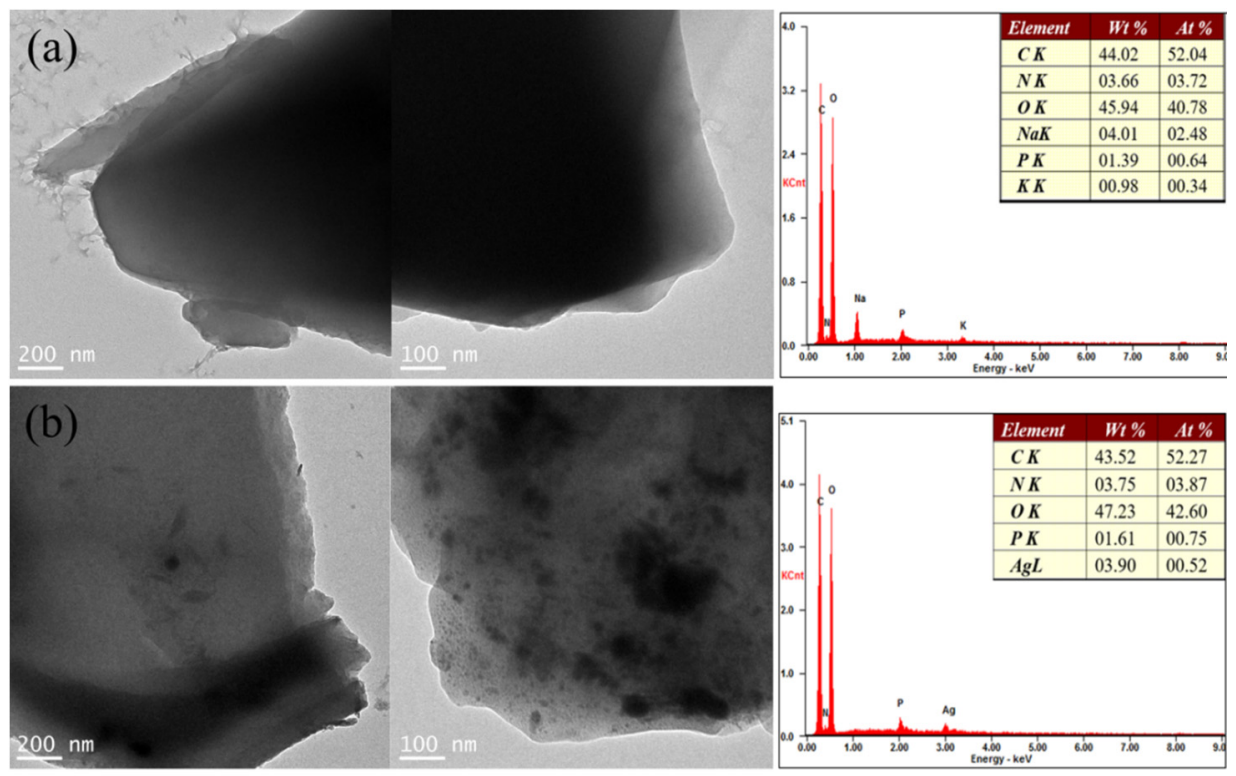

(c)
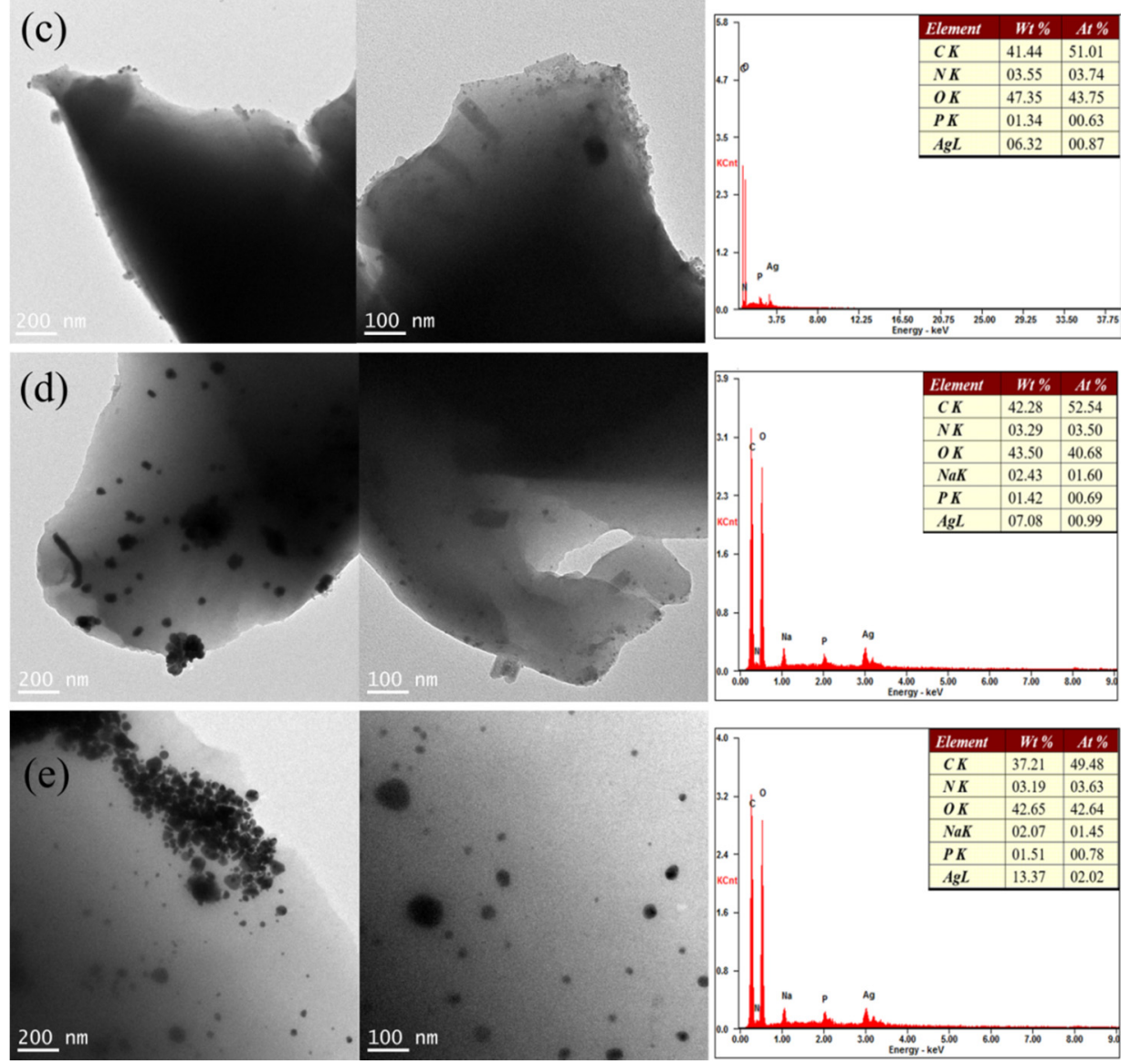

Figure 4. Element analysis and TEM images of CD-CA/PDA (a), CD-CA/PDA-0.5Ag (b), CDCA/PDA-1Ag (c), CD-CA/PDA-2Ag (d) and CD-CA/PDA-4Ag (e).

Based on the above characterisation and previous research, we have concluded that the antibacterial mechanism of CD-CA/PDA-xAg can be divided into the following three aspects. Firstly, due to the small particle size of AgNPs and the promotion of the effective adsorption active groups of CD-CA/PDA, AgNPs were easily attached to the cell walls of bacteria [40]. Then AgNPs could quickly bind to the sulfhydryl group (-SH) of the enzyme protein, which interfered with the formation of peptidoglycan in the cell wall. The cell wall 
was destroyed, and the bacteria were inactivated. Subsequently, after the cell membrane was exposed, the respiratory metabolism of the bacteria was severely affected by the impact of the nano silver attached to the cell membrane; bacterial permeability was compromised, which eventually led to the leakage of cell contents and death [41].

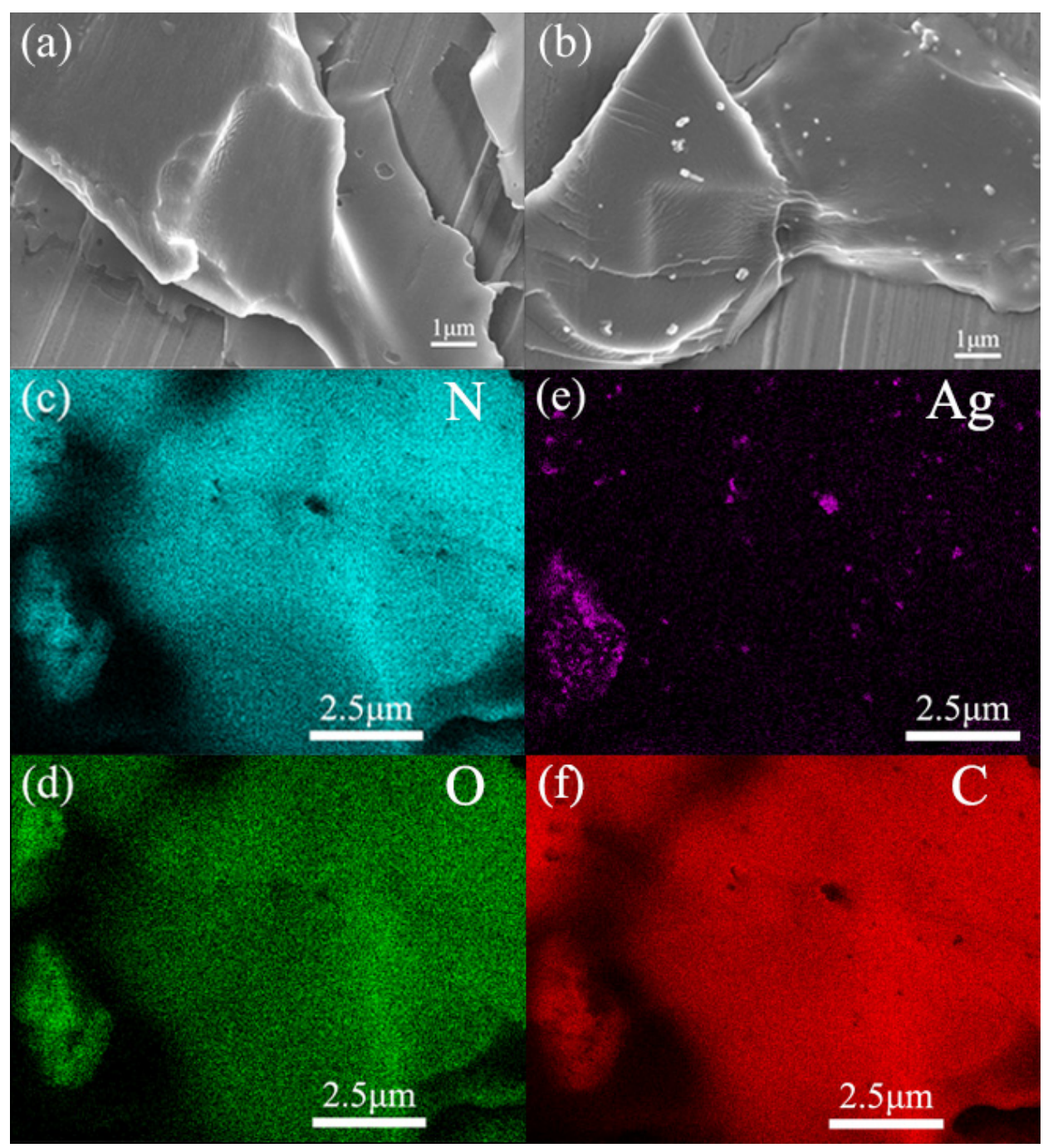

Figure 5. FESEM images of CD-CA/PDA (a) and CD-CA/PDA-0.5Ag (b); FESEM-EDS element mapping of $\mathrm{N}(\mathbf{c}), \mathrm{O}(\mathbf{d}), \mathrm{Ag}(\mathbf{e})$ and $\mathrm{C}(\mathbf{f})$ in CD-CA/PDA-0.5Ag.

Secondly, after CD-CA/PDA-xAg entered the solution, AgNPs were easily oxidised to release silver ions when exposed to water in an aerobic environment. Activities such as cell phagocytosis and pinocytosis promoted the delivery of silver ions into the cell. It binded to the sulfhydryl group (-SH) of the enzyme protein, replaced the hydrogen bond of the bacterial DNA base, reacted with imino and carboxyl groups, causing problems such as inactivation of the bacterial enzyme protein and inability to replicate DNA, ultimately leading to cell apoptosis [42].

Thirdly, the AgNPs in CD-CA/PDA-xAg produced reactive oxygen species (ROS) during the oxidation process. ROS with extremely strong oxidising ability can destroy the cell wall of macromolecular organisms and directly break the cell membrane [43], which oxidises the unsaturated fatty acids and proteases.

\subsection{Optimisation of Antibacterial Adsorbent}

To investigate the influence of initial $\mathrm{pH}$ on the adsorption of cationic pollutants, the adsorption capacity of CD-CA/PDA-0.5Ag with the initial concentration of $300 \mathrm{mg} / \mathrm{L}$ 
$\mathrm{MB}$ under different initial $\mathrm{pH}$ values of the solution are shown in Figure 6. When $\mathrm{pH}$ was varied from 2 to about 12, the removal capacities of MB on CD-CA/PDA-0.5Ag continuously increased, which was attributed to the gradual deprotonation of catechol and carboxyl groups [24]. An increase in the surface charge density favored the adsorption of the positively charged $\mathrm{MB}$ by electrostatic interactions with the negatively charged $\mathrm{COO}^{-}$.

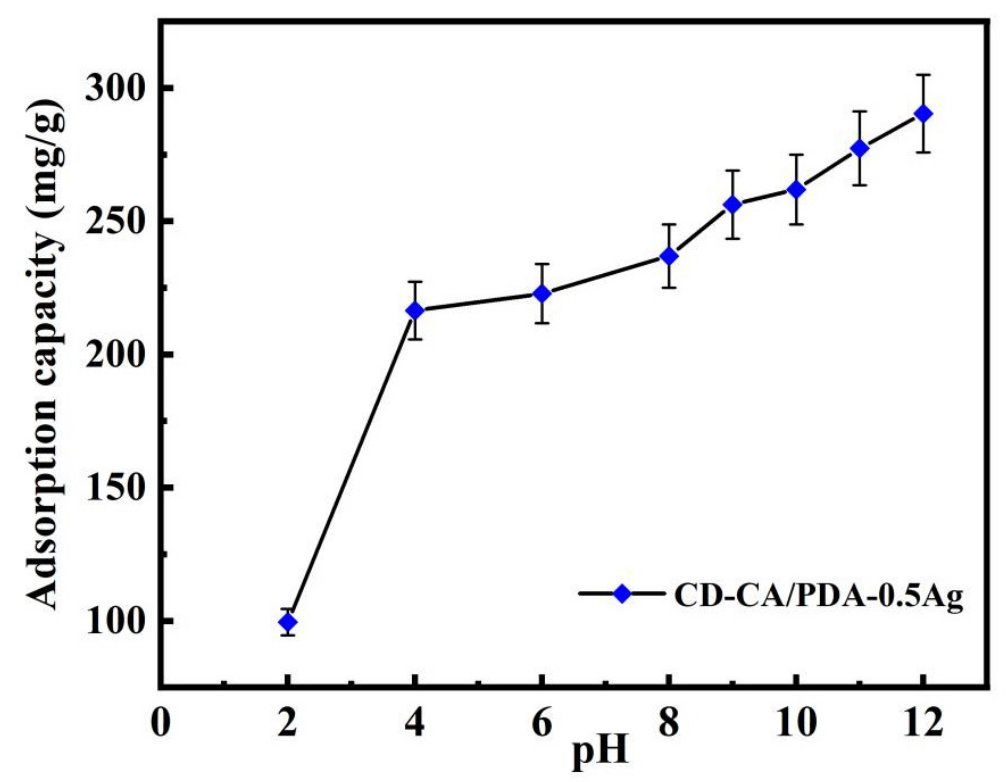

Figure 6. Effect of initial $\mathrm{pH}$ on adsorption capacity of CD-CA/PDA-0.5Ag. $\left([\mathrm{MB}]_{0}=300 \mathrm{mg} / \mathrm{L}\right.$, [adsorbent] $=1 \mathrm{~g} / \mathrm{L}$, contract time $=12 \mathrm{~h}, \mathrm{~T}=25^{\circ} \mathrm{C}$ ).

It was observed that the adsorption capacity increased rapidly from $99.5 \mathrm{mg} / \mathrm{g}$ to $216.5 \mathrm{mg} / \mathrm{g}$ with increasing $\mathrm{pH}$ from 2 to 4 , then it was progressively maintained to $224 \mathrm{mg} / \mathrm{g}$ from 4 to 7 . Although there was a slight increase in the adsorption capacity of the CD-CA/PDA-0.5Ag by changing the $\mathrm{pH}$ from 7 to 12 , this change was not significant [14]. These findings indicated that the adsorbents in this study can be applied to a wide range of $\mathrm{pH}$ in water treatment processes. Moreover, according to the results obtained from the practical treatment of dyed and microbial wastewater, $\mathrm{pH} 5.5$ was selected as best $\mathrm{pH}$ value for carrying out the subsequent experiments [44].

To investigate the influence of Ag content on the adsorption of cationic pollutants, $\mathrm{CD}$ CA/PDA and CD-CA/PDA-xAg were used to treat MB solution of 600 and $300 \mathrm{mg} / \mathrm{L}$. The adsorption performance with varying time is shown in Figure 7a,b. With MB at $600 \mathrm{mg} / \mathrm{L}$, contact time of $3 \mathrm{~h}$ and adsorbent dosage of $1 \mathrm{~g} / \mathrm{L}$, the adsorption capacity gradually decreased with the gradual increase in Ag. The adsorption capacities corresponded to $535.93,488.76,376.43,192.18$ and $134.69 \mathrm{mg} / \mathrm{g}$. When the concentration of MB was changed to $300 \mathrm{mg} / \mathrm{L}$, the adsorption capacity of the five different silver content adsorbents were $281.33,287.03,297.05,184.83$ and $131.37 \mathrm{mg} / \mathrm{g}$. When the concentration of $\mathrm{Ag}$ reached $\mathrm{X}=1$, a decrease in the adsorption capacity of CD-CA/PDA-xAg was observed because of the reduction in $\mathrm{Ag}^{+}$during the material synthesis process, which consumed the catechol groups of the adsorption active sites. Thus, the phenolic hydroxyl groups were oxidised to benzoquinone groups [45].

A comparison of the adsorption rates of the two adsorbents under different concentration is illustrated in Table 1. When the material was loaded with a small amount of $\mathrm{Ag}$, the phenolic hydroxyl groups on the surface of the material were consumed, and the roughness largely increased due to the modification of Ag (as shown in the SEM images), which promoted the adsorption rate in the early stage. However, increasing the amount of silver led to the consumption of a large amount of phenolic hydroxyl groups, whereas the rough surface characteristics provided by silver did not bring about a great improve- 
ment in adsorption. The pre-adsorption efficiency and the adsorption capacity were also greatly reduced.
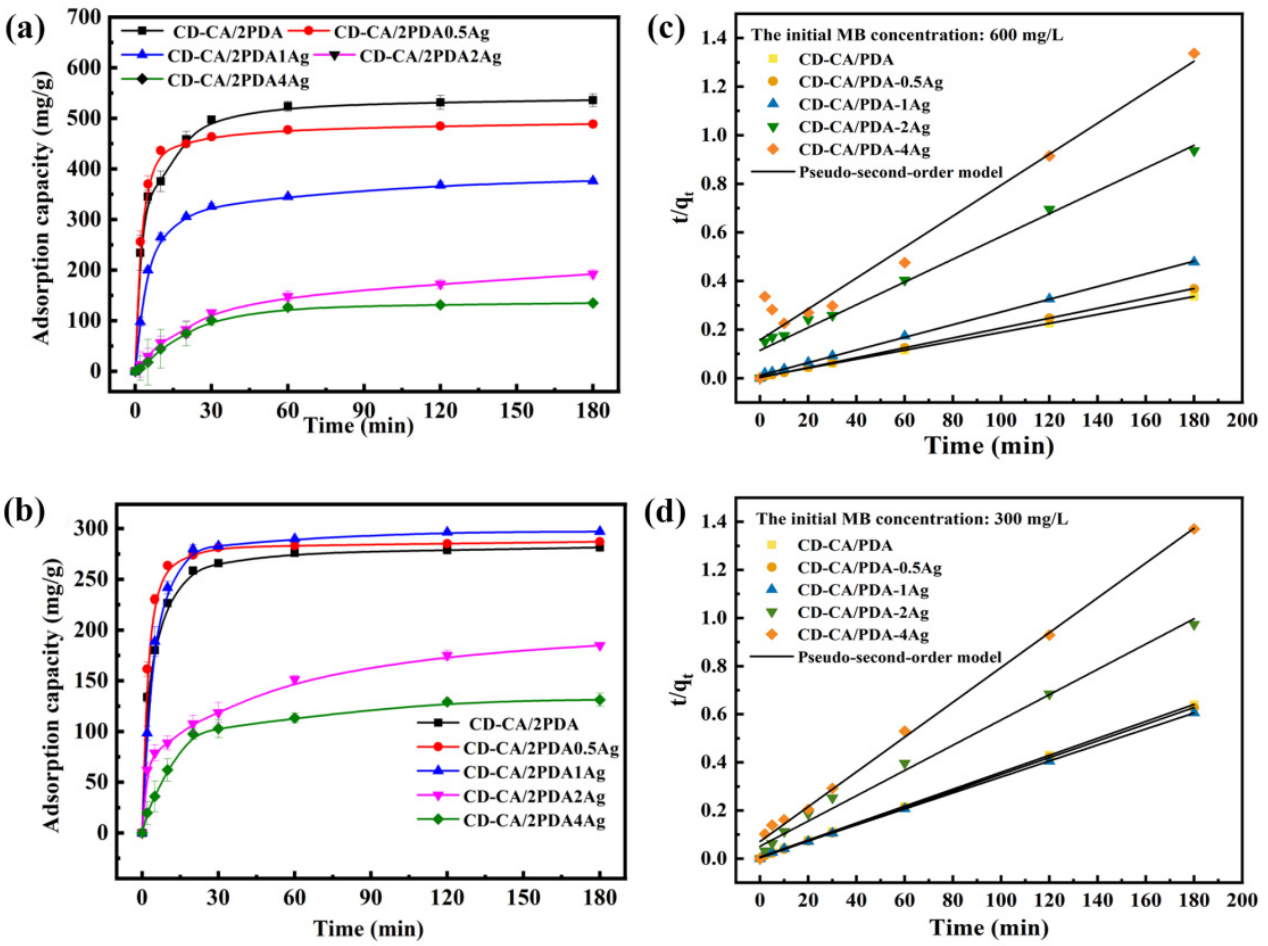

Figure 7. The adsorption property of CD-CA/PDA-xAg at the initial MB concentration of $600 \mathrm{mg} / \mathrm{L}$ (a) and $300 \mathrm{mg} / \mathrm{L}$ (b); adsorption kinetics of CD-CA/PDA-xAg adsorption of MB when the initial concentration is (c) $600 \mathrm{mg} / \mathrm{L}$ and (d) $300 \mathrm{mg} / \mathrm{L}$ fitted by pseudo-second order model.

Table 1. The adsorption capacity of CD-CA/PDA-xAg when time is $10 \mathrm{~min}$ of the initial MB concentration of $600 \mathrm{mg} / \mathrm{L}$ and $300 \mathrm{mg} / \mathrm{L}$.

\begin{tabular}{ccc}
\hline Concentration of $\mathbf{M B}$ & Adsorbent & Adsorption Capacity \\
\hline & CD-CA/PDA & $375.75 \pm 20.24 \mathrm{mg} / \mathrm{g}$ \\
& CD-CA/PDA-0.5Ag & $436.67 \pm 5.05 \mathrm{mg} / \mathrm{g}$ \\
$600 \mathrm{mg} / \mathrm{L}$ & CD-CA/PDA-1Ag & $264.90 \pm 9.09 \mathrm{mg} / \mathrm{g}$ \\
& CD-CA/PDA-2Ag & $57.06 \pm 12.28 \mathrm{mg} / \mathrm{g}$ \\
& CD-CA/PDA-4Ag & $44.28 \pm 38.33 \mathrm{mg} / \mathrm{g}$ \\
\hline \multirow{3}{*}{$300 \mathrm{mg} / \mathrm{L}$} & CD-CA/PDA & $226.69 \pm 1.97 \mathrm{mg} / \mathrm{g}$ \\
& CD-CA/PDA-0.5Ag & $263.64 \pm 1.47 \mathrm{mg} / \mathrm{g}$ \\
& CD-CA/PDA-1Ag & $241.82 \pm 6.29 \mathrm{mg} / \mathrm{g}$ \\
& CD-CA/PDA-2Ag & $88.72 \pm 6.88 \mathrm{mg} / \mathrm{g}$ \\
& CD-CA/PDA-4Ag & $61.99 \pm 11.10 \mathrm{mg} / \mathrm{g}$ \\
\hline
\end{tabular}

The pseudo-second-order kinetic fitting of CD-CA/PDA-xAg adsorption of $\mathrm{MB}$ at the initial concentrations of 600 and $300 \mathrm{mg} / \mathrm{L}$ is shown in Figure 7c,d. In addition, the fitted parameter of pseudo-second order is summarised in Table 2. The pseudo-second-order equation according to Formula (2) and the variant Formula (3), as follows:

$$
\begin{aligned}
q_{t} & =\frac{K_{2} q_{e}^{2} t}{\left(1+K_{2} q_{e} t\right)} \\
\frac{t}{q_{t}} & =\frac{1}{K_{2} q_{e}^{2}}+\frac{1}{q_{e}} t
\end{aligned}
$$


where $t$ ( $\mathrm{min}$ ) represents the contact time and $K_{2}(\mathrm{~g} / \mathrm{mg} \mathrm{min})$ is kinetic rate constants of the pseudo-second-order adsorption kinetic model. $q_{t}(\mathrm{mg} / \mathrm{g})$ and $q_{e}(\mathrm{mg} / \mathrm{g})$ are the amount of the adsorbed mass per unit amount of adsorbent at time $t$ and at equilibrium, respectively.

Table 2. Pseudo-second-order kinetic parameters for the adsorption of the initial MB concentrations of $600 \mathrm{mg} / \mathrm{L}$ and $300 \mathrm{mg} / \mathrm{L}$.

\begin{tabular}{|c|c|c|c|c|c|}
\hline Concentration of $\mathrm{MB}$ & Adsorbent & $q_{e}^{\mathrm{cal}}(\mathrm{mg} / \mathrm{g})$ & $q_{e}^{\exp (\mathrm{mg} / \mathrm{g})}$ & $k^{2} 10^{-3}(\mathrm{~g} / \mathrm{mg} \min )$ & $\mathbf{R}^{2}$ \\
\hline \multirow{5}{*}{$600 \mathrm{mg} / \mathrm{L}$} & CD-CA/PDA & 543.5 & 535.9 & 0.6924 & 0.9996 \\
\hline & CD-CA/PDA- $0.5 \mathrm{Ag}$ & 492.6 & 488.8 & 1.4113 & 0.9999 \\
\hline & CD-CA/PDA-1Ag & 383.1 & 376.4 & 0.5903 & 0.9991 \\
\hline & $\mathrm{CD}-\mathrm{CA} / \mathrm{PDA}-2 \mathrm{Ag}$ & 213.2 & 192.2 & 0.1922 & 0.9761 \\
\hline & CD-CA/PDA-4Ag & 157.0 & 134.7 & 0.2581 & 0.9490 \\
\hline \multirow{5}{*}{$300 \mathrm{mg} / \mathrm{L}$} & $\mathrm{CD}-\mathrm{CA} / \mathrm{PDA}$ & 284.1 & 281.3 & 1.8302 & 0.9998 \\
\hline & CD-CA/PDA-0.5Ag & 288.2 & 287.0 & 3.6598 & 0.9999 \\
\hline & CD-CA/PDA-1Ag & 301.2 & 297.1 & 1.5330 & 0.9997 \\
\hline & $\mathrm{CD}-\mathrm{CA} / \mathrm{PDA}-2 \mathrm{Ag}$ & 190.5 & 184.8 & 0.5411 & 0.9909 \\
\hline & CD-CA/PDA-4Ag & 138.3 & 131.4 & 0.7364 & 0.9955 \\
\hline
\end{tabular}

The adsorption behaviours are better matched with the pseudo-second-level kinetic model, because it has a higher $\mathrm{R}^{2}$ constant $(>0.999)$. The equilibrium adsorption capacity qecal calculated by pseudo-second-order kinetics was closer to the experimental results $q_{e}{ }^{\text {exp }}$, which indicated that the adsorption mechanism of this type of adsorbent was under the action of static electricity [46] rather than the diffusion and mass transfer of pollutant molecules [24].

\subsection{The Antibacterial Performance of Adsorbent}

The Gram-negative bacterium E. coli is a prokaryote. Its cell wall comprises very few peptidoglycans and lipopolysaccharides, but teichoic acid is commonly thick. It has a multi-layer nature that is roughly divided into three parts. The outer layer is composed of lipopolysaccharide and porin, which hinders the entry of a large number of fat-soluble substances and is also water permeable. The middle layer has strong mechanical properties and maintains the basic shape of the cell; it is mostly composed of peptidoglycan. The innermost layer is the cytoplasmic membrane, which carries a large number of proteins for cell life activities and prevents the leakage of intracellular proteins [47].

The experimental effects of CD-CA/PDA and CD-CA/PDA-xAg on E. coli bacteriostatic zone are shown in Figure 8. The numbers 0, 0.5, 1, 2 and 4 represent CD-CA/PDA, CD-CA/PDA-0.5Ag, CD-CA/PDA-Ag, CD-CA/PDA-2Ag and CD-CA/PDA-4Ag, respectively. In the three parallel experiments, no obvious zone of inhibition was found around the No. 0 filter paper sheet, indicating that CD-CA/PDA had no inhibitory effect on the growth of $E$. coli on agar medium. The size of the inhibition zone of the three groups of CD-CA/PDA-0.5Ag experiments reached about $14 \mathrm{~mm}$. Compared with the previous EDS data, it was shown that the silver content of CD-CA/PDA-0.5Ag was only 3.90\%, indicating that a smaller amount of AgNPs was enough for an efficient antibacterial activity. The bacteriostatic zone increased with the gradual increase in the silver content in CD-CA/PDA-xAg. The inhibition zone reached a diameter of approximately $20 \mathrm{~mm}$ in the CD-CA/PDA-4Ag; the zone was smooth and flat without any bacterial growth. The content of AgNPs was the key factor for the antibacterial activity.

S. aureus is a Gram-positive bacterium. It is different from E. coli, because it has a thicker cell wall and simple components [48]. In addition, it has considerable amounts of peptidoglycan and lipopolysaccharide with no teichoic acid. It also has a stronger cell protection than E. coli. S. aureus has long been regarded as high-risk bacteria that can infect humans. In the field of public health, S. aureus can cause wound infections, induce local purulent infections and may cause systemic inflammation, e.g., arthritis and sepsis [49]. At the same time, as a common food-borne pathogen, $S$. aureus can cause staphylococcus food 
poisoning and is one of the major pathogens responsible for food-borne illnesses in various areas in the world, including the United States, Europe, China, Canada and Japan [50].
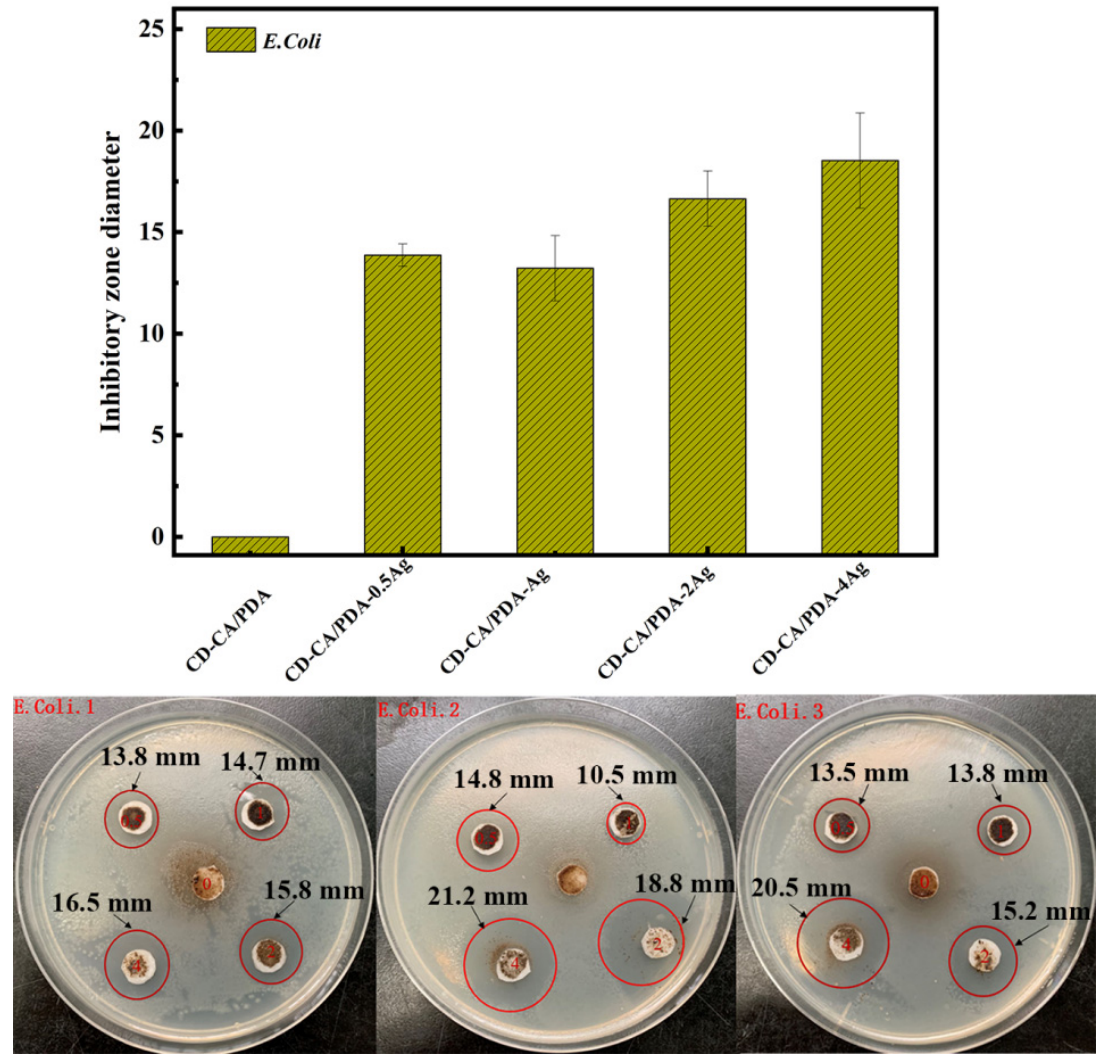

Figure 8. Diffusion inhibition zone of CD-CA/PDA and CD-CA/PDA-xAg to E. coli.

The experimental effects of CD-CA/PDA and CD-CA/PDA-xAg on S. aureus bacteriostatic zone are shown in Figure 9. The indications of the numbers 0, 0.5, 1, 2 and 4 are consistent with those of the E. coli inhibition zone experiment. Similar to the experimental phenomenon of $E$. coli bacteriostatic zone, no obvious inhibition zone was formed around CD-CA/PDA, which had no inhibitory effect on S. aureus. With increasing AgNPs content, the antibacterial circle increased in size, indicating that AgNPs is of great importance for the antibacterial activity.

When comparing the experimental effects on the inhibition zone of E. coli and S. aureus, the following results were found. (1) With increasing silver content, the size of the inhibition zone formed by the CD-CA/PDA-xAg antibacterial material on E. coli increased and was clear compared to that of $S$. aureus. (2) The inhibition zone formed by CD-CA/PDA-xAg with the same AgNPs on E. coli was significantly larger than that of $S$. aureus. This finding may be due to the fact that $S$. aureus is a Gram-positive bacterium, it is thicker and has a mechanically stronger cell wall which provides a better protective effect on cells compared with E. coli [51].

To accurately explore the direct effect of CD-CA/PDA-xAg on E. coli and S. aureus in the bacterial solution, a colony forming unit experiment with CD-CA/PDA-xAg was performed. The effect is shown in Figure S1. The inhibitory effect of CD-CA/PDA was approximately $20 \%$. CD-CA/PDA had a certain killing effect on the two bacteria in the solution, which could be attributed to CD-CA/PDA's adsorption of microorganisms on its surface, which blocked the transport channels for nutrient and waste recycling, leading to the death of the bacteria [52]. However, the antibacterial effect was relatively general. With the gradual increase in the content of AgNPs, the inhibitory efficiency of CD-CA/PDA-xAg on the two bacteria increased significantly. The inhibition efficiencies of CD-CA/PDA-0.5Ag, CD-CA/PDA-1Ag, CD-CA/PDA-2Ag and CD-CA/PDA-4Ag on 
E. coli and S. aureus reached $63.27 \%, 36.28 \%, 60.62 \%$ and $81.96 \%$ and $61.06 \%, 42.48 \%, 52.22 \%$ and $31.08 \%$ respectively. In this colony experiment, an increased content of AgNPs did not lead to a stronger antibacterial performance. The inhibitory efficiency of CD-CA/PDA$0.5 \mathrm{Ag}$ on the two bacteria was significantly higher than those of CD-CA/PDA-1Ag and CD-CA/PDA-2Ag. TEM results showed that with the gradual increase in AgNPs content, the particle size of the material also gradually increased. Previous studies showed that the particle size of the antibacterial material affected its antibacterial effect. The larger the particle size the smaller the antibacterial performance. A smaller particle size increases the chance of contact with bacteria on the surface of the material and also contributes to the release of silver ions [42].

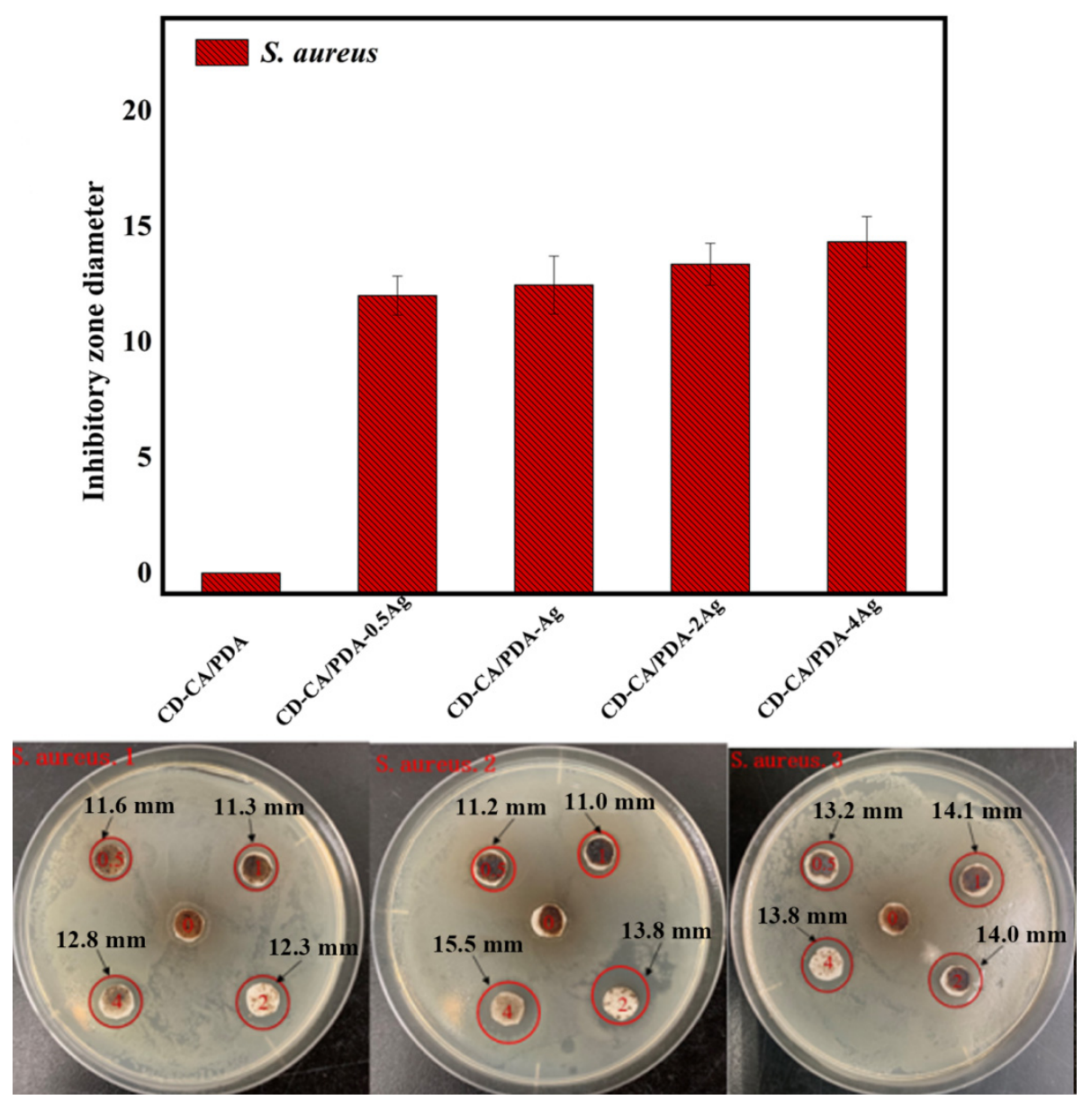

Figure 9. Diffusion inhibition zone of CD-CA/PDA and CD-CA/PDA-xAg to S. aureus.

\section{Conclusions}

CD-CA/PDA, a product of polydopamine-modified citrate cyclodextrin polymer, was used as an adsorption matrix material. Silver nanoparticles were loaded on the material to successfully synthesise the multifunctional antibacterial adsorbent CD-CA/PDA-xAg, which can be used to address microbial problems in water treatment. XPS, FTIR, TEM and FESEM analyses showed that silver loading did not cause any major changes in the structure and properties of the matrix material. Silver loading was relatively uniform without obvious agglomeration. With a gradual increase in the silver content, the inhibition zone gradually became larger, and the antibacterial effect of the material increased, whereas the adsorption performance (adsorption capacity and rate) for $\mathrm{MB}$ gradually decreased. CD-CA/PDA-0.5Ag showed a good balanced adsorption performance in $\mathrm{MB}$ removal and antibacterial performance against $E$. coli and $S$. aureus. It provides a ref- 
erence for the improvement of the adsorption performance and antibacterial properties through modification.

Supplementary Materials: The following are available online at https:/ /www.mdpi.com/article/10 $.3390 / w 13213004 / s 1$, Figure S1: colony forming unit tests of CD-CA/PDA and CD-CA/PDA-xAg to E. coli (a) and S. aureus (b).

Author Contributions: Validation, X.W.; methodology, H.C.; investigation, J.W.; writing—original draft preparation, X.W.; writing —review and editing, Y.Z. (Yi Zhou); resources, Y.Z. (Yanbo Zhou) and C.C.; funding acquisition, Y.Z. (Yanbo Zhou). All authors have read and agreed to the published version of the manuscript.

Funding: This research was funded by the National Natural Science Foundation of China (51778230), the Program of Shanghai Outstanding Technology Leaders (20XD1433900), and the Fundamental Research Funds for the Central Universities.

Institutional Review Board Statement: Not applicable.

Informed Consent Statement: Not applicable.

Data Availability Statement: Not applicable.

Conflicts of Interest: The authors declare no conflict of interest related to this research.

\section{List of Abbreviations}

$\begin{array}{ll}\text { AgNPs } & \text { Silver nanoparticles } \\ \text { CA } & \text { Citric acid } \\ \text { CD } & \text { Cyclodextrin } \\ \text { CD-CA } & \text { Citric acid-cross-linked } \beta \text {-cyclodextrin polymer } \\ \text { CD-CA/PDA } & \text { Polydopamine composite adsorbent } \\ \text { CD-CA/PDA-xAg } & \text { Silver-modified } \beta \text {-cyclodextrin polymer polydopamine } \\ \text { DH } & \text { Dopamine hydrochloride } \\ \text { E. coli. } & \text { Escherichia coli } \\ \text { MB } & \text { Methylene blue } \\ \text { PDA } & \text { Polydopamine } \\ \text { S. auerus } & \text { Staphylococcus aureus } \\ \text { Tris } & \text { Tris(hydroxymethyl)aminomethane }\end{array}$

\section{References}

1. Tchinsa, A.; Hossain, M.F.; Wang, T.; Zhou, Y. Removal of organic pollutants from aqueous solution using metal organic frameworks (MOFs)-based adsorbents: A review. Chemosphere 2021, 284, 131393. [CrossRef]

2. Borthakur, P.; Boruah, P.K.; Das, M.R.; Kulik, N.; Minofar, B. Adsorption of $17 \alpha$-ethynyl estradiol and $\beta$-estradiol on graphene oxide surface: An experimental and computational study. J. Mol. Liq. 2018, 269, 160-168. [CrossRef]

3. Faysal Hossain, M.D.; Akther, N.; Zhou, Y. Recent advancements in graphene adsorbents for wastewater treatment: Current status and challenges. Chin. Chem. Lett. 2020, 31, 2525-2538. [CrossRef]

4. Duan, C.; Ma, T.; Wang, J.; Zhou, Y. Removal of heavy metals from aqueous solution using carbon-based adsorbents: A review. J. Water Process Eng. 2020, 37, 101339. [CrossRef]

5. Zhou, Y.; Cheng, G.; Chen, K.; Lu, J.; Lei, J.; Pu, S. Adsorptive removal of bisphenol A, chloroxylenol, and carbamazepine from water using a novel $\beta$-cyclodextrin polymer. Ecotoxicol. Environ. Saf. 2019, 170, 278-285. [CrossRef]

6. Liu, Q.; Zhou, Y.; Lu, J.; Zhou, Y. Novel cyclodextrin-based adsorbents for removing pollutants from wastewater: A critical review. Chemosphere 2020, 241, 125043. [CrossRef] [PubMed]

7. WHO. Guidelines for Drinking-Water Quality, 3rd ed.; WHO: Geneva, Switzerland, 2004.

8. Benstoem, F.; Becker, G.; Firk, J.; Kaless, M.; Wuest, D.; Pinnekamp, J.; Kruse, A. Elimination of micropollutants by activated carbon produced from fibers taken from wastewater screenings using hydrothermal carbonization. J. Environ. Manag. 2018, 211, 278-286. [CrossRef]

9. Pinto, A.J.; $\mathrm{Xi}, \mathrm{C}$.; Raskin, L. Bacterial community structure in the drinking water microbiome is governed by filtration processes. Environ. Sci. Technol. 2012, 46, 8851-8859. [CrossRef] [PubMed]

10. Kotp, Y.H. Removal of organic pollutants using polysulfone ultrafiltration membrane containing polystyrene silicomolybdate nanoparticles: Case study: Borg El Arab area. J. Water Process Eng. 2019, 30, 100553. [CrossRef] 
11. Borthakur, P.; Boruah, P.K.; Hussain, N.; Sharma, B.; Das, M.R.; Matić, S.; Řeha, D.; Minofar, B. Experimental and Molecular Dynamics Simulation Study of Specific Ion Effect on the Graphene Oxide Surface and Investigation of the Influence on Reactive Extraction of Model Dye Molecule at Water-Organic Interface. J. Phys. Chem. C 2016, 120, 14088-14100. [CrossRef]

12. Upadhyay, U.; Sreedhar, I.; Singh, S.A.; Patel, C.M.; Anitha, K.L. Recent advances in heavy metal removal by chitosan based adsorbents. Carbohydr. Polym. 2021, 251, 117000. [CrossRef]

13. Borthakur, P.; Aryafard, M.; Zara, Z.; David, Ř.; Minofar, B.; Das, M.R.; Vithanage, M. Computational and experimental assessment of $\mathrm{pH}$ and specific ions on the solute solvent interactions of clay-biochar composites towards tetracycline adsorption: Implications on wastewater treatment. J. Environ. Manag. 2021, 283, 111989. [CrossRef] [PubMed]

14. Zhan, H.; Wang, Y.; Mi, X.; Zhou, Z.; Wang, P.; Zhou, Q. Effect of graphitic carbon nitride powders on adsorption removal of antibiotic resistance genes from water. Chin. Chem. Lett. 2020, 31, 2843-2848. [CrossRef]

15. Wang, J.; Cheng, G.; Lu, J.; Chen, H.; Zhou, Y. PDA-cross-linked beta-cyclodextrin: A novel adsorbent for the removal of BPA and cationic dyes. Water Sci. Technol. 2020, 81, 2337-2350. [CrossRef]

16. Wang, J.; Lu, J.; Zhou, Y.; Zhou, Y. Multifunctional Antibacterial Materials for the Control of Hazardous Microbes and Chemicals: A Review. ACS EST Water 2021, 1, 479-497. [CrossRef]

17. Dong, Z.; Tagliavini, M.; Darmadi, J.; Trouillet, V.; Schäfer, A.I.; Levkin, P.A. Regeneration of $\beta$-Cyclodextrin Based Membrane by Photodynamic Disulfide Exchange-Steroid Hormone Removal from Water. Adv. Mater. Interfaces 2020, 7, 1902100. [CrossRef]

18. Khalil, A.M.; Schäfer, A.I. Cross-linked $\beta$-cyclodextrin nanofiber composite membrane for steroid hormone micropollutant removal from water. J. Membr. Sci. 2021, 618, 118228. [CrossRef]

19. Liu, Y.; Jia, J.; Gao, T.; Wang, X.; Yu, J.; Wu, D.; Li, F. One-pot fabrication of antibacterial $\beta$-cyclodextrin-based nanoparticles and their superfast, broad-spectrum adsorption towards pollutants. J. Colloid Interface Sci. 2020, 576, 302-312. [CrossRef]

20. Schäfer, A.I.; Stelzl, K.; Faghih, M.; Sen Gupta, S.; Krishnadas, K.R.; Heißler, S.; Pradeep, T. Poly(ether sulfone) Nanofibers Impregnated with $\beta$-Cyclodextrin for Increased Micropollutant Removal from Water. ACS Sustain. Chem. Eng. 2018, 6, $2942-2953$. [CrossRef]

21. Liu, J.; Zhang, C.; Zhang, S.; Yu, H.; Xie, W. A versatile $\beta$-cyclodextrin functionalized silver nanoparticle monolayer for capture of methyl orange from complex wastewater. Chin. Chem. Lett. 2020, 31, 539-542. [CrossRef]

22. Zhou, Y.; He, J.; Lu, J.; Liu, Y.; Zhou, Y. Enhanced removal of bisphenol A by cyclodextrin in photocatalytic systems: Degradation intermediates and toxicity evaluation. Chin. Chem. Lett. 2020, 31, 2623-2626. [CrossRef]

23. Leclercq, L.; Nardello-Rataj, V. How to improve the chemical disinfection of contaminated surfaces by viruses, bacteria and fungus? Eur. J. Pharm. Sci. 2020, 155, 105559. [CrossRef]

24. Chen, H.; Zhou, Y.; Wang, J.; Lu, J.; Zhou, Y. Polydopamine modified cyclodextrin polymer as efficient adsorbent for removing cationic dyes and $\mathrm{Cu}^{2+}$. J. Hazard. Mater. 2020, 389, 121897. [CrossRef] [PubMed]

25. Di, H.; Qiaoxia, L.; Yujie, Z.; Jingxuan, L.; Yan, W.; Yinchun, H.; Xiaojie, L.; Song, C.; Weiyi, C. Ag nanoparticles incorporated tannic acid/nanoapatite composite coating on Ti implant surfaces for enhancement of antibacterial and antioxidant properties. Surf. Coat. Technol. 2020, 399, 126169. [CrossRef]

26. Fan, M.; Si, J.; Xu, X.; Chen, L.; Chen, J.; Yang, C.; Zhu, J.; Wu, L.; Tian, J.; Chen, X.; et al. A versatile chitosan nanogel capable of generating AgNPs in-situ and long-acting slow-release of $\mathrm{Ag}^{+}$for highly efficient antibacterial. Carbohydr. Polym. 2021, 257, 117636. [CrossRef]

27. Rabbi, M.A.; Rahman, M.M.; Minami, H.; Yamashita, N.; Habib, M.R.; Ahmad, H. Magnetically responsive antibacterial nanocrystalline jute cellulose nanocomposites with moderate catalytic activity. Carbohydr. Polym. 2021, 251, 117024. [CrossRef] [PubMed]

28. Yang, W.; Hu, W.; Zhang, J.; Wang, W.; Cai, R.; Pan, M.; Huang, C.; Chen, X.; Yan, B.; Zeng, H. Tannic acid/Fe ${ }^{3+}$ functionalized magnetic graphene oxide nanocomposite with high loading of silver nanoparticles as ultra-efficient catalyst and disinfectant for wastewater treatment. Chem. Eng. J. 2021, 405, 126629. [CrossRef]

29. Somlyai-Sipos, L.; Baumli, P.; Sycheva, A.; Kaptay, G.; Szőri-Dorogházi, E.; Kristály, F.; Mikó, T.; Janovszky, D. Development of Ag nanoparticles on the surface of Ti powders by chemical reduction method and investigation of their antibacterial properties. Appl. Surf. Sci. 2020, 533, 147494. [CrossRef]

30. Volkov, A.O.; Golubenko, D.V.; Yaroslavtsev, A.B. Development of solid polymer composite membranes based on sulfonated fluorocopolymer for olefin/paraffin separation with high permeability and selectivity. Sep. Purif. Technol. 2021, $254,117562$. [CrossRef]

31. Fathalipour, S.; Mardi, M. Synthesis of silane ligand-modified graphene oxide and antibacterial activity of modified graphenesilver nanocomposite. Mat. Sci. Eng. C-Mater. 2017, 79, 55-65. [CrossRef] [PubMed]

32. Yan, Y.; Zhou, X.; Yu, P.; Li, Z.; Zheng, T. Characteristics, mechanisms and bacteria behavior of photocatalysis with a solid $\mathrm{Z}$-scheme $\mathrm{Ag} / \mathrm{AgBr} / \mathrm{g}-\mathrm{C}_{3} \mathrm{~N}_{4}$ nanosheet in water disinfection. Appl. Catal. A-Gen. 2020, 590, 117282. [CrossRef]

33. Huang, W.; Hu, Y.; Li, Y.; Zhou, Y.; Niu, D.; Lei, Z.; Zhang, Z. Citric acid-crosslinked $\beta$-cyclodextrin for simultaneous removal of bisphenol A, methylene blue and copper: The roles of cavity and surface functional groups. J. Taiwan Inst. Chem. E 2018, 82, 189-197. [CrossRef]

34. Zhou, Y.; Hu, Y.; Huang, W.; Cheng, G.; Cui, C.; Lu, J. A novel amphoteric $\beta$-cyclodextrin-based adsorbent for simultaneous removal of cationic/anionic dyes and bisphenol A. Chem. Eng. J. 2018, 341, 47-57. [CrossRef] 
35. Tang, J.; Shi, Z.; Berry, R.M.; Tam, K.C. Mussel-inspired green metallization of silver nanoparticles on cellulose nanocrystals and their enhanced catalytic reduction of 4-nitrophenol in the presence of $\beta$-cyclodextrin. Ind. Eng. Chem. Res. 2015, 54, 3299-3308. [CrossRef]

36. Yang, Z.; Wu, Y.; Wang, J.; Cao, B.; Tang, C.Y. In situ reduction of silver by polydopamine: A novel antimicrobial modification of a thin-film composite polyamide membrane. Environ. Sci. Technol. 2016, 50, 9543-9550. [CrossRef]

37. Zangmeister, R.A.; Morris, T.A.; Tarlov, M.J. Characterization of polydopamine thin films deposited at short times by autoxidation of dopamine. Langmuir 2013, 29, 8619-8628. [CrossRef]

38. Cui, K.; Yan, B.; Xie, Y.; Qian, H.; Wang, X.; Huang, Q.; He, Y.; Jin, S.; Zeng, H. Regenerable urchin-like Fe $\mathrm{O}_{4} @ P D A-A g$ hollow microspheres as catalyst and adsorbent for enhanced removal of organic dyes. J. Hazard. Mater. 2018, 350, 66-75. [CrossRef] [PubMed]

39. Hong, S.; Na, Y.S.; Choi, S.; Song, I.T.; Kim, W.Y.; Lee, H. Non-covalent self-assembly and covalent polymerization co-contribute to polydopamine formation. Adv. Funct. Mater. 2012, 22, 4711-4717. [CrossRef]

40. Yang, C.; Jian, R.; Huang, K.; Wang, Q.; Feng, B. Antibacterial mechanism for inactivation of E. coli by AgNPs@polydoamine/titania nanotubes via speciation analysis of silver ions and silver nanoparticles by cation exchange reaction. Microchem. J. 2021, 160, 105636. [CrossRef]

41. Tortella, G.R.; Rubilar, O.; Durán, N.; Diez, M.C.; Martínez, M.; Parada, J.; Seabra, A.B. Silver nanoparticles: Toxicity in model organisms as an overview of its hazard for human health and the environment. J. Hazard. Mater. 2020, 390, 121974. [CrossRef]

42. Li, D.; Chen, S.; Zhang, K.; Gao, N.; Zhang, M.; Albasher, G.; Shi, J.; Wang, C. The interaction of Ag $\mathrm{O}_{2}$ nanoparticles with Escherichia coli: Inhibition-sterilization process. Sci. Rep. 2021, 11, 1703. [CrossRef] [PubMed]

43. Redza-Dutordoir, M.; Averill-Bates, D.A. Activation of apoptosis signalling pathways by reactive oxygen species. Biochim. Biophys. Acta (BBA)-Mol. Cell Res. 2016, 1863, 2977-2992. [CrossRef]

44. Osma, J.F.; Saravia, V.; Toca-Herrera, J.L.; Couto, S.R. Sunflower seed shells: A novel and effective low-cost adsorbent for the removal of the diazo dye Reactive Black 5 from aqueous solutions. J. Hazard. Mater. 2007, 147, 900-905. [CrossRef]

45. Ye, W.; Shi, X.; Su, J.; Chen, Y.; Fu, J.; Zhao, X.; Zhou, F.; Wang, C.; Xue, D. One-step reduction and functionalization protocol to synthesize polydopamine wrapping Ag/graphene hybrid for efficient oxidation of hydroquinone to benzoquinone. Appl. Catal. B-Environl. 2014, 160-161, 400-407. [CrossRef]

46. Su, P.; Gao, X.; Zhang, J.; Djellabi, R.; Yang, B.; Wu, Q.; Wen, Z. Enhancing the adsorption function of biochar by mechanochemical graphitization for organic pollutant removal. Front. Environ. Sci. Eng. 2021, 15, 130. [CrossRef]

47. Boags, A.T.; Samsudin, F.; Khalid, S. Binding from Both Sides: TolR and Full-Length OmpA Bind and Maintain the Local Structure of the E. coli Cell Wall. Structure 2019, 27, 713-724.e2. [CrossRef]

48. Cui, J.; Shao, Y.; Zhang, H.; Zhang, H.; Zhu, J. Development of a novel silver ions-nanosilver complementary composite as antimicrobial additive for powder coating. Chem. Eng. J. 2020, 420, 127633. [CrossRef]

49. Zhang, K.; Du, Y.; Si, Z.; Liu, Y.; Turvey, M.E.; Raju, C.; Keogh, D.; Ruan, L.; Jothy, S.L.; Reghu, S.; et al. Enantiomeric glycosylated cationic block co-beta-peptides eradicate Staphylococcus aureus biofilms and antibiotic-tolerant persisters. Nat. Commun. 2019, 10, 4792. [CrossRef] [PubMed]

50. Xu, Z.; Xie, J.; Soteyome, T.; Peters, B.M.; Shirtliff, M.E.; Liu, J.; Harro, J.M. Polymicrobial interaction and biofilms between Staphylococcus aureus and Pseudomonas aeruginosa: An underestimated concern in food safety. Curr. Opin. Food Sci. 2019, $26,57-64$. [CrossRef]

51. Moniri Javadhesari, S.; Alipour, S.; Mohammadnejad, S.; Akbarpour, M.R. Antibacterial activity of ultra-small copper oxide (II) nanoparticles synthesized by mechanochemical processing against S. aureus and E. coli. Mat. Sci. Eng. C-Mater. 2019, 105, 110011. [CrossRef] [PubMed]

52. Li, M.; Li, L.; Lin, S. Efficient antimicrobial properties of layered double hydroxide assembled with transition metals via a facile preparation method. Chin. Chem. Lett. 2020, 31, 1511-1515. [CrossRef] 